Egyptian Journal of Aquatic Biology \& Fisheries

Zoology Department, Faculty of Science,

Ain Shams University, Cairo, Egypt.

ISSN $1110-6131$

Vol. 25(1): $795-819$ (2021)

www.ejabf.journals.ekb.eg

\title{
Ecological, Hematological and Parasitological Studies on Oreochromis niloticus Linnaeus 1757 in the Nile Delta Region, Egypt
}

\author{
Rana H. Omar; Ahmed A. Hagras; Ahmed M. El-Naggar and Mohamed I. Mashaly* \\ Zoology Department, Faculty of Science, Mansoura University, Egypt. \\ "Corresponding Author: Dr.moh_mashaly@mans.edu.eg
}

\section{ARTICLE INFO}

Article History:

Received: Nov. 8, 2021

Accepted: Dec. 30, 2020

Online: Feb. 22, 2021

Keywords:

Oreochromis niloticus,

water analysis,

Nile Delta,

blood analysis,

prevalence

\begin{abstract}
A total of 36 water samples and 600 specimens of the cichlid fish, Oreochromis niloticus Linnaeus 1757; were seasonally collected from three water habitats in the Nile Delta region throughout winter 2016 till autumn 2017. An investigation was conducted to determine the relationship between water analysis and the hematological and parasitological data of studied fish. Thus, the effect of water quality was estimated by using parasites as bioindicators and hematological analysis as biomonitors in the aquatic ecosystem. According to physical and chemical water analysis, a very high significant difference of EC, $\mathrm{DO}_{2}, \mathrm{BOD}_{5}, \mathrm{~K}^{+}, \mathrm{Na}^{+}, \mathrm{Ca}^{+2}, \mathrm{Cl}^{-}, \mathrm{HCO}_{3}^{-}$, TDS and $\mathrm{SO}_{4}{ }^{+2}$ was reported between different study sites $(\mathrm{p} \leq 0.001)$. Moreover, hematological studies of fish samples revealed a very high significant difference of G.S.H. and Testosterone in males and G.S.H., MDA and Progesterone in females $(\mathrm{p} \leq 0.001)$, and a highly significant difference of MDA in males $(p \leq 0.01)$. In addition, a significant difference of CAT of males $(\mathrm{p} \leq 0.01)$ was also detected between different study sites. Parasitologically, there was a significant difference in prevalence, mean intensity, and abundance of $C$. halli in $O$. niloticus in different study sites $(\mathrm{p} \leq$ $0.05)$. Each factor was morphometrically analyzed, and variations were hence discussed. The difference in environmental characteristics, despite the stability of the geographical location, led to variations in both fish blood analysis and parasitic infestation level in the study sites. Therefore, fish and parasites are evidently used as biological biomarkers to assess their environment.
\end{abstract}

\section{INTRODUCTION}

Water pollution occurs when unwanted substances enter the water and affect water quality (Alrumman et al., 2016) that harm the environment and human health (Briggs, 2003). Such phenomenon is due to domestic and industrial wastewater leaping from water tank leaks, the ocean dumping of radioactive wastes and atmospheric deposition (Khan et al., 2013).

In Egypt, 20\% of the white animal protein production depends on fish. The most common farmed fish species is Oreochromis niloticus (Elgohary et al., 2020), among 
which is Tilapia, that constitutes about $43.5 \%$ of farmed fish production and $24 \%$ of the total fisheries production (GAFRD, 2007), and recently, it has been used as a model for toxicology in bioremediation studies (Sayed et al., 2020). Parasitic diseases account for $80 \%$ of fish diseases (Tayel et al., 2020). Monogenic parasites are recognized as useful biomarkers of environmental quality due to their expected numerical response to chemical contamination (Khan \& Thulin, 1991; MacKenzie, 1999). Monogenic organisms are often exposed to a number of pollutants of low and medium concentrations, but they disappear at high concentrations (Marcogliese et al., 1998; Moles \& Wade, 2001; Khan \& Payne, 2004). Ectoparasitic monogeneans are successful bioindicators or biomonitors of human interference and disturbance (Marcogliese, 2005).

Fish blood parameters can be used as efficient and sensitive indicators to detect the health of the fish. The haematological profile in fish farms may indicate physiological status and fish health, so that alternative standard blood diagnostic methods are used to establish and assess stress and / or the influencing performance of the disease state (Tavares-Dias \& Moraes, 2004; Barbieri et al., 2017; Bosisio et al., 2017; Fazio, 2019). Additionally, these changes in blood parameters depend on several factors, such as species, temperature, age, light, nutrition, sexual maturity, cyclical changes in health, water quality, dissolved oxygen, gender, static water slopes and handling, stress, transportation, size, feeding and breeding density as well as microbial infections and parasitic infections (Ranzani-Paiva et al., 2003; Tavares-Dias and Moraes, 2004; Val et al., 2016; Fazio, 2019). The present study was conducted to investigate the relationship of ecological studies with hematological and parasitological responses of Oreochromis niloticus in different habitats at a specific geographical area of the Nile Delta region in Egypt.

\section{MATERIALS AND METHODS}

\section{The fish host and the Study area:}

A total of 36 water samples and 600 specimens of the cichlid fish, constricted on the common distributed species; Oreochromis niloticus Linnaeus 1757; were collected seasonally intervals from three study sites throughout winter 2016 to autumn 2017. The hosts were identified morphologically according to Trewavas (1983). The three study sites were located at Dakahlyia Governorate, Sherbin, Kafr El-Dabosy village namely, Damietta branch of the River Nile, Drain no.1 (Parallel to Damietta branch of the River Nile at this area) and Pumping Station (Connecting canal with pumping station between the other two study sites), and selected for the water and host collection samples (Figure $1)$.

\subsection{The River Nile's locality}

The River Nile (RN) was selected as a reference site in the present study selected. It is located in Kafr El-Dabosy, Sherbin city, Dakahlia Governorate, $165 \mathrm{Km}$ north of Cairo, North Egypt, with the following coordinates: 31¹0'55.4412" N 31³0'22.7952" E. 


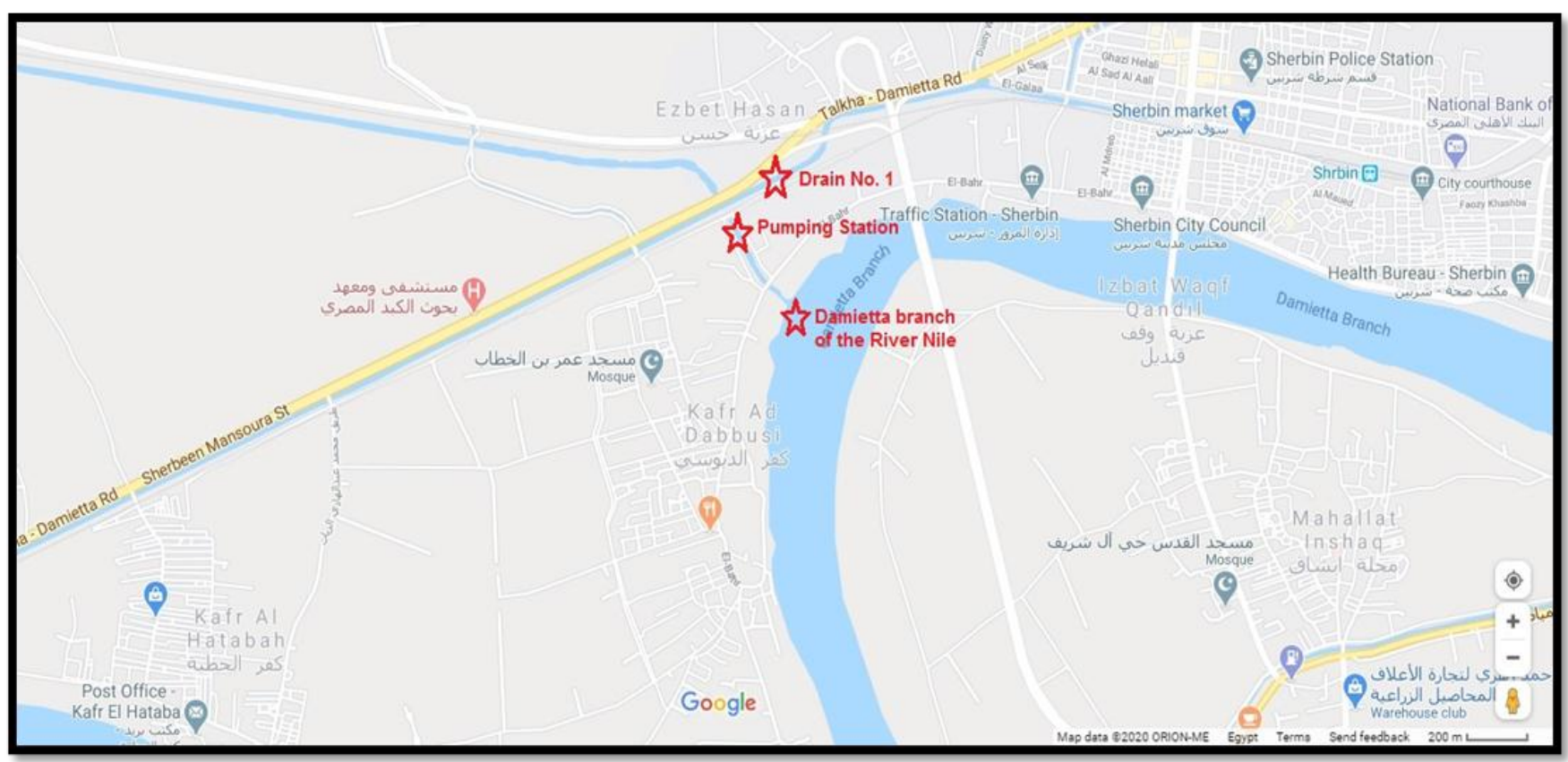

Figure (1). Google map showing the location of the investigated sites at Kafr El-Dabosy village and comprised three localities namely, Damietta.

\subsection{Drain No. 1}

Drain no.1 (D1) is located near Sherbin city, $50 \mathrm{~km}$ north El-Mansoura city, Dakahlia Governorate; Egypt. It has the following coordinates: 31 $10^{\prime} 55.4412^{\prime \prime} \mathrm{N}$ $31^{\circ} 30^{\prime 22.7952 " ~ E . ~ D r a i n ~ N o .1 ~ r e c e i v e s ~ u r b a n ~ s e w a g e, ~ l a r g e ~ a m o u n t s ~ o f ~ t h e ~ d o m e s t i c ~}$ discharge from agriculture drainage, in addition to some industrial discharges from small factories and illegal workshops established in the vicinity of the drain during the last few decades.

\subsection{Pumping station}

A pumping station (PS) is located in the connecting canal between the River Nile and Drain No. 1, pumping the excess water of the Drain No. 1 to the River Nile. But, the canal has been closed for about ten years; a status that results in the exsistance of stagnant water on the two sides of the pumping station facing the River Nile from one side and the Drain No. 1 from the other. This area contains heavy water grasses which may affect the nature of fish behavior.

\section{Sampling of the host fish}

Seasonally, about 150 fish samples were collected from all site (about 50 from each). Alive fish were brought to the lab for blood samples' withdrawal that were meanwhile dissected with clean stainless-steel instruments. To make three sub-samples, the collected tissues from five fish individuals of identical species were pooled. Muscle organs were isolated and kept frozen in the same day of collection for further analysis. Then, the living captured fish were preserved by immediate immersion in $10 \%$ formalin and transported to the laboratory to be ready for examination of monogenean parasites. The hosts were identified morphologically according to Trewavas (1983). 


\section{Determination of the host biological parameters}

Fish weight, length and sex were recorded.

\section{Blood collection and hematological examination}

Examination of blood sample for hematological analysis is achieved through the technique of puncturing the red blood vessels, caudal peduncle and ventral caudate, and the dermis of non-double size is removed from the end of the base direction of the anal fin. The inner central layout, from about $1 \mathrm{~cm}$ in length to the sterile anal needle at an angle of $45^{\circ}$, is fixedly tapered heparinized disposable syringes, in the direction of craniodorsal fish. The described method is fully recommended.

\subsection{Determination of the parameters of the blood picture} (1977).

Stabilization of Blood samples was performed according to Dacie and lewis

\subsubsection{Haemoglobin $(\mathrm{Hb})$}

Cyanohemiglobin method is used to investigate hemoglobin in fish blood.The principle of this method depends on the release of hemoglobin from red blood cells by metamorphosis. The hemoglobin content was assessed according to Drabkin (1946).

\subsubsection{Red blood cells count (RBCs)}

The red blood cell counts in fish blood were examined in heparin treated with Hayem solution at a ratio of 1: 200 according to Hesser (1960).

\subsubsection{Hematocrit value (Ht)}

The hematocrit content measures the corpuscular volume in relation to the total volume of blood; namely, packed cell volume. Hematocrit value was determined according to Snieszko (1960).

\subsubsection{White blood cells count (WBCs)}

Determined of the white blood cells count in fish was applied in heparinized blood, which was diluted with a solution at a ratio of 1:200. For the determination of WBCs, fresh (newly prepared) solution cannot be used; it should be left for about two weeks, it must be filtered prior to use. White blood cell count after 24 hours still heparinized blood stored at temperatures of up to $4{ }^{\circ} \mathrm{C}$ (Shaw, 1930).

\subsection{Measurement of enzyme activity, antioxidant and oxidative stress marker}

Following gentle blood withdrawal from the caudal vein, each sample of blood was allowed to coagulate for 15-20 min. Then, the settled blood sample was subjected to centrifugation $(3000 \mathrm{rpm}, 10 \mathrm{~min})$ to isolate serum. Next, the isolated serum was kept at $20^{\circ} \mathrm{C}$ for later enzyme activity and hormones analysis.

\subsubsection{Determination of catalase (CAT) enzyme activity}

It was determined by enzymatic chromatography using ready-made kits provided by Alpha, USA according to Cohen et al. (1970). 


\subsubsection{Determination of glutathione (GSH) anitoxidant}

Determination of GSH calorimetry prepared by Bio-diagnostic kit, Egypt according to Beutler et al. (1963).

\subsubsection{Determination of malondialdehyde (MDA) oxidative stress marker:}

It was determined by enzymatic colorimetric method using ready-made diagnostic kits provided by Bio-Diagnostic, Egypt according to Satoh (1978).

\subsection{Hormones analysis}

\subsubsection{Testosterone}

Testosterone hormone is diagnosed by using the IMMULITE and IMMULITE 1000 Analyzer quantitative measurement of serum testosterone according to Matthiessen (2003).

\subsubsection{Progesterone}

Progesterone hormone was diagnosed using the IMMULITE Analyzer and IMMULITE 1000 to quantify progesterone in blood according to Bergquist et al. (1983).

\section{Identification of the monogenean parasites}

The identification of the monogenean gill parasite; Cichlidogyrus halli was according to Paperna (1960) and Yamaguti (1963).

\section{Statistical analysis and treatment of data}

The individuals of each parasite species were counted seasonally per each fish. The prevalence (\%), mean intensity and abundance were calculated. The terms; prevalence, mean intensity and abundance were used in accordance with the recommendations of Margolis et al. (1982) who defined the prevalence as the percentage of infestation per all examined fish, and mean intensity as the mean number of parasites recorded per a single infected fish.

Differences in the distribution of the hematological analysis, TOC and infestation of monogenean species between males and females of $O$. niloticus fishes were tested statistically using the Student's $t$-Test on SPSS package (version: IBM Spss Statistics 25). On the other hand, differences in the hematological analysis, TOC and infestation levels of monogenean parasites, between different study sites as well as among the four gill arches, were tested using the same statistical software;namely, One-Way ANOVA Test.

Two trends of multivariate analysis are commonly followed: classification and ordination. Both trends are merited in helping to understand the significance of differences in prevalence, mean intensity and abundant values in the study sites at different seasons and environmental (water) parameters. A wide variety of techniques, following each of these trends, has been developed. These techniques were reviewed in detail by Crovello (1970). On the other hand, the ordination technique applied here is Canonical Correspondence Analysis (CCA-biplot) using CANOCO (ter-Braak, 1986, 1988), in which the relationships between the prevalence values of monogenean parasites and water parameters can be indicated on the ordination diagram; where points represent 
the study sites at different seasons, and arrows represent physical and chemical water variables.

\section{RESULTS}

\section{Physical analyses of water samples}

Table 1 shows the seasonal variations of the physical factors of water samples collected from the Damietta branch of the River Nile (RN), Drain no.1 (D1) and Pumping Station (PS) during winter 2016 to autumn 2017. As shown in Table 1, there was a remarkable increase in EC during winter in $\mathrm{D} 1(1.38 \mathrm{dS} / \mathrm{m})$, with a noticed high value $(0.99 \mathrm{dS} / \mathrm{m})$ of mean EC in D1, compared to corresponding values in RN and PS (0.39 and $0.30 \mathrm{dS} / \mathrm{m}$, respectively). A remarkable increase in $\mathrm{DO}_{2}$ and $\mathrm{BOD}_{5}$ during winter in $\mathrm{RN}\left(9.05\right.$ and $5.56 \mathrm{mg} / \mathrm{L}$, respectively) with a remarkable increase in mean $\mathrm{DO}_{2}(6.65$ $\mathrm{mg} / \mathrm{L}$ ) in the RN was observed. On the other hand, there was a remarkable decrease in temperature during winter $\left(18.00{ }^{\circ} \mathrm{C}\right)$ and $\mathrm{DO}_{2}$ during autumn $(3.53 \mathrm{mg} / \mathrm{L})$ and $\mathrm{BOD}_{5}$ during summer $(2.05 \mathrm{mg} / \mathrm{L})$ in $\mathrm{D} 1$, with a remarkable decrease in mean values of $\mathrm{DO}_{2}$ and $\mathrm{BOD}_{5}(4.36$ and $2.67 \mathrm{mg} / \mathrm{L}$, respectively) in $\mathrm{D} 1$.

Table (1): Seasonal fluctuations of the physical parameters in subsurface water from River Nile, Drain No.1 and Pumping Station.

\begin{tabular}{|c|c|c|c|c|c|c|c|c|c|c|c|c|c|c|c|}
\hline \multirow{3}{*}{ Season } & \multicolumn{15}{|c|}{ Physical water analyses } \\
\hline & \multicolumn{3}{|c|}{$\begin{array}{c}\mathbf{T} \\
\left({ }^{\circ} \mathrm{C}\right)\end{array}$} & \multicolumn{3}{|c|}{ pH } & \multicolumn{3}{|c|}{$\begin{array}{c}\mathbf{E C} \\
(\mathrm{dS} / \mathrm{m})\end{array}$} & \multicolumn{3}{|c|}{$\begin{array}{c}\mathbf{D O}_{2} \\
(\mathrm{mg} / \mathrm{L})\end{array}$} & \multicolumn{3}{|c|}{$\begin{array}{c}\text { BOD }_{\mathbf{5}} \\
(\mathrm{mg} / \mathrm{L})\end{array}$} \\
\hline & $\mathbf{R N}$ & D1 & PS & RN & D1 & PS & $\mathbf{R N}$ & D1 & PS & $\mathbf{R N}$ & D1 & PS & $\mathbf{R N}$ & D1 & PS \\
\hline "Winter & 20.50 & 18.00 & 19.90 & 7.85 & 7.90 & 7.84 & 0.67 & 1.38 & 0.27 & 9.05 & 25.50 & 6.55 & (25.65 & 3.25 & 4.95 \\
\hline Spring & 29.97 & 30.27 & 29.53 & 8.14 & 8.18 & 8.23 & 0.28 & 0.95 & 0.28 & 6.73 & 3.80 & 6.07 & 4.37 & \begin{tabular}{|l|l|}
2.57 & \\
\end{tabular} & 5.00 \\
\hline Summer & 30.50 & 30.40 & 30.50 & 8.14 & 8.38 & 8.20 & 0.26 & 0.75 & 0.27 & 5.85 & 4.60 & 4.45 & 4.15 & 2.05 & 3.60 \\
\hline Autumn & 25.30 & 25.27 & 25.17 & 8.18 & 8.29 & 8.25 & 0.35 & 0.88 & 0.36 & 4.97 & 3.53 & 4.93 & 4.97 & 2.80 & 4.87 \\
\hline Mean & 26.57 & 25.98 & 26.28 & 8.08 & 8.19 & 8.13 & 0.39 & 0.99 & 0.30 & 6.65 & 4.36 & 5.50 & 4.78 & \begin{tabular}{|l|l|}
2.67 \\
\end{tabular} & 4.60 \\
\hline SD \pm & 4.67 & 5.83 & 4.84 & 0.16 & 0.21 & 0.20 & 0.19 & 0.27 & 0.04 & 1.76 & 0.89 & 0.97 & 0.67 & 0.50 & 0.67 \\
\hline
\end{tabular}

Statistically, The one-way ANOVA test revealed that there was no significant difference in temperature and $\mathrm{pH}$ between different study sites $(\mathrm{p}>0.05)$. On the other hand, the one-way ANOVA test revealed that there was a very high significant difference of $\mathrm{EC}, \mathrm{DO}_{2}$ and $\mathrm{BOD}_{5}$ between different study sites $(\mathrm{p} \leq 0.001)$. Multiple range comparisons (PostHoc tests: Tukey HSD) detected very high significant differences between RN and D1 and between D1 and PS $(\mathrm{p} \leq 0.001)$ in $\mathrm{EC}$ and $\mathrm{BOD}_{5}$ and highly significant differences between $\mathrm{RN}$ and $\mathrm{D} 1(\mathrm{p} \leq 0.01)$ in $\mathrm{DO}_{2}$.

\section{Chemical analyses of water samples}

Table 2 shows the seasonal variations of the chemical factors of water samples, collected from the Damietta branch of the River Nile, Drain no.1 and Pumping Station during winter 2016 to autumn 2017. Table 2 shows the exsistance of a remarkable increase in mean $\mathrm{K}^{+}$in PS $(5.81 \mathrm{mg} / \mathrm{L})$ with noticed high values $(169.83,6.51,27.73$, 
87.13, 52.92, 611.04, 303.52 mg/L) of mean $\mathrm{Na}^{+}, \mathrm{Mg}^{+2}, \mathrm{Ca}^{+2}, \mathrm{Cl}^{-}, \mathrm{HCO}_{3}{ }^{-}$, TDS and $\mathrm{SO}_{4}{ }^{-2}$ respectively, in D1, compared to corresponding values in PS and RN. On the other hand, there was a remarkable decrease in the mean of $\mathrm{Na}^{+}, \mathrm{Cl}^{-}$, TDS, $\mathrm{SO}_{4}{ }^{-2}$ and $\mathrm{N}$ in PS (43.09, $23.09,188.25,85.05$ and $6.76 \mathrm{mg} / \mathrm{L}$, respectively) with a remarkable decrease in $\mathrm{Mg}^{+2}$ $(1.08 \mathrm{mg} / \mathrm{L})$ during winter in $\mathrm{RN}$.

Table (2): Seasonal fluctuations of some chemical parameters $(\mathrm{mg} / \mathrm{L})$ in subsurface water from River Nile, Drain No.1 and Pumping Station.

\begin{tabular}{|c|c|c|c|c|c|c|c|c|c|c|c|c|c|c|c|}
\hline \multirow[b]{2}{*}{ Season } & \multicolumn{15}{|c|}{ Chemical water analyses } \\
\hline & \multicolumn{3}{|c|}{$\mathbf{K}^{+}$} & \multicolumn{3}{|c|}{$\mathrm{Na}^{+}$} & \multicolumn{3}{|c|}{$\mathrm{Mg}^{+2}$} & \multicolumn{3}{|c|}{$\mathrm{Ca}^{+2}$} & \multicolumn{3}{|c|}{$\mathrm{Cl}^{-}$} \\
\hline Winter & 4.50 & 5.67 & 5.67 & 112.89 & 212.72 & 28.83 & 1.08 & 14.56 & 2.14 & 23.23 & 42.57 & 21.06 & 53.72 & 180.46 & 25.61 \\
\hline Spring & 6.00 & 4.50 & 5.90 & 50.57 & 164.27 & 46.31 & 3.43 & 3.11 & 2.51 & 9.07 & 25.00 & 9.90 & 20.18 & 62.46 & 17.60 \\
\hline Autumn & 4.33 & 4.83 & 5.67 & 56.35 & 163.45 & 58.76 & 3.71 & 4.48 & 2.96 & 11.73 & 23.47 & 13.20 & 26.70 & 55.62 & 26.70 \\
\hline Mean & 5.02 & 4.88 & 5.81 & 64.96 & 169.83 & 43.09 & 2.85 & 6.51 & 2.85 & 13.21 & 27.73 & 13.79 & 30.36 & 87.13 & 23.09 \\
\hline SD \pm & 0.76 & 0.55 & 0.17 & 32.65 & 30.93 & 12.66 & 1.20 & 5.39 & 0.70 & 6.81 & 10.12 & 5.04 & 15.85 & 62.43 & 4.08 \\
\hline Season & \multicolumn{3}{|c|}{$\mathrm{HCO}_{3}^{-}$} & \multicolumn{3}{|c|}{ TDS } & \multicolumn{3}{|c|}{$\mathrm{SO}_{4}^{+2}$} & \multicolumn{3}{|c|}{$\mathbf{N}$} & \multicolumn{3}{|c|}{$\mathbf{P}$} \\
\hline Spring & 27.39 & 51.25 & 27.26 & 184.58 & 585.90 & 184.69 & 89.11 & 319.36 & 93.89 & 8.92 & 9.14 & 5.97 & 0.12 & 0.14 & 0.12 \\
\hline Summer & 29.87 & 52.99 & 28.87 & 165.16 & 477.05 & 172.29 & 75.49 & 247.52 & 74.96 & 8.51 & 7.56 & 6.30 & 0.12 & 0.13 & 0.12 \\
\hline Autumn & 40.63 & 54.17 & 45.14 & 221.23 & 561.71 & 230.83 & 97.86 & 303.46 & 101.51 & 7.35 & 6.93 & 7.35 & 0.13 & 0.13 & 0.13 \\
\hline Mean & 33.21 & 52.92 & 32.17 & 228.45 & 611.04 & 188.25 & 111.84 & 303.52 & 85.05 & 8.01 & 8.28 & 6.76 & 0.12 & 0.14 & 0.13 \\
\hline SD \pm & 5.86 & 1.22 & 8.68 & 79.71 & 146.60 & 29.51 & 49.58 & 40.84 & 15.08 & 0.83 & 1.23 & 0.74 & 0.00 & 0.01 & 0.01 \\
\hline
\end{tabular}

Statistically, the one-way ANOVA test revealed that there was a very high significant difference of $\mathrm{K}^{+}, \mathrm{Na}^{+}, \mathrm{Ca}^{+2}, \mathrm{Cl}^{-}, \mathrm{HCO}_{3}{ }^{-}$, TDS and $\mathrm{SO}_{4}{ }^{-2}$ between different study sites $(\mathrm{p} \leq 0.001)$. Multiple range comparisons (PostHoc tests: Tukey HSD) detected very high significant differences between $\mathrm{RN}$ and D1 and between D1 and PS ( $\mathrm{p} \leq 0.001)$ in $\mathrm{Na}^{+}, \mathrm{Ca}^{+2}, \mathrm{Cl}^{-}, \mathrm{HCO}_{3}^{-}$, TDS and $\mathrm{SO}_{4}{ }^{-2}$ and very highly significant differences between $\mathrm{RN}$ and PS and between D1 and PS $(\mathrm{p} \leq 0.001)$ in $\mathrm{K}^{+}$. On the other hand, the one-way ANOVA test revealed that there was highly significant difference of $\mathrm{Mg}^{+2}, \mathrm{~N}$ and $\mathrm{P}$ between different study sites $(\mathrm{p} \leq 0.01)$. Multiple range comparisons (PostHoc tests: Tukey HSD) detected very high significant differences between RN and D1 and between D1 and PS $(\mathrm{p} \leq 0.001)$ in $\mathrm{Mg}^{+2}$ and $\mathrm{P}$ and highly significant differences between D1 and PS $(\mathrm{p} \leq 0.01)$ in $\mathrm{N}$. 


\section{Hematological analyses of fish samples}

Table 3 shows the seasonal variations of the blood picture of fish samples collected from the Damietta branch of the River Nile, Drain no.1 and Pumping Station during the investigation period. Table (3) reveals that there is a remarkable increase in mean $\mathrm{RBC}_{\mathrm{s}}$ in male fish in $\mathrm{D} 1\left(3.77 \times 10^{6} / \mu \mathrm{L}\right)$. Statistically, the one-way ANOVA test illustrated that there was no significant difference of all blood picture parameters of male and female $O$. niloticus between different study sites ( $\mathrm{p}>0.05$ ).

Table (3): Seasonal variations of hematological analysis of the Oreochromis niloticus in the study sites.

\begin{tabular}{|c|c|c|c|c|c|c|c|c|c|c|c|c|c|}
\hline \multirow{3}{*}{ Sex } & \multirow{3}{*}{ Season } & \multicolumn{12}{|c|}{ Blood Pictures } \\
\hline & & \multicolumn{3}{|c|}{$\begin{array}{l}\text { Hemoglobin } \\
(\mathrm{g} / \mathrm{dl})\end{array}$} & \multicolumn{3}{|c|}{$\begin{array}{l}\text { R.B.C.s. } \\
\left(\times 10^{6} / \mu \mathrm{L}\right)\end{array}$} & \multicolumn{3}{|c|}{$\begin{array}{c}\text { Hematocrit } \\
(\%)\end{array}$} & \multicolumn{3}{|c|}{$\begin{array}{c}\text { WBCs } \\
\left(\times 10^{3} \text { cells } / \mathrm{cm}\right)\end{array}$} \\
\hline & & $\mathbf{R N}$ & D1 & PS & $\mathbf{R N}$ & D1 & PS & $\mathbf{R N}$ & D1 & PS & $\mathbf{R N}$ & D1 & PS \\
\hline \multirow{6}{*}{$\frac{\stackrel{0}{\sigma}}{\Sigma}$} & Winter & 7.10 & 8.80 & 8.23 & 2.55 & 3.81 & 2.93 & 21.30 & 25.65 & 24.70 & 12.75 & 17.25 & 15.50 \\
\hline & Spring & 7.90 & 9.86 & 7.35 & 3.13 & 4.74 & 2.63 & 24.77 & 30.30 & 22.25 & 17.90 & 16.83 & 13.90 \\
\hline & Summer & 8.93 & 9.20 & 8.05 & 3.17 & 3.26 & 2.89 & 26.70 & 27.60 & 24.23 & 14.98 & 18.25 & 15.78 \\
\hline & Autumn & 10.75 & 9.30 & 10.80 & 3.75 & 3.28 & 3.77 & 32.25 & 27.90 & 32.80 & 15.45 & 12.83 & 15.40 \\
\hline & Mean & 8.67 & 9.29 & 8.61 & 3.15 & 3.77 & 3.05 & 26.26 & 27.86 & 25.99 & 15.27 & 16.29 & 15.14 \\
\hline & $\mathrm{SD} \pm$ & 1.21 & 0.44 & 1.51 & 0.30 & 0.70 & 3.08 & 3.28 & 1.91 & 4.66 & 1.35 & 2.38 & 0.84 \\
\hline \multirow{6}{*}{ 䒕 } & Winter & 6.85 & 7.30 & 7.40 & 2.45 & 2.60 & 2.85 & 20.55 & 21.90 & 24.60 & 12.85 & 13.40 & 16.70 \\
\hline & Spring & 8.28 & 8.63 & 9.28 & 3.38 & 3.01 & 3.84 & 25.60 & 26.03 & 28.05 & 20.23 & 15.26 & 15.48 \\
\hline & Summer & 9.88 & 8.73 & $\begin{array}{l}8.83 \\
\end{array}$ & 3.49 & 3.12 & 3.12 & 29.63 & 26.30 & 26.48 & 14.78 & 15.57 & 16.45 \\
\hline & Autumn & 11.28 & 9.27 & 11.16 & 3.95 & 3.27 & 3.89 & 33.84 & 27.80 & 33.48 & 15.78 & 15.97 & 16.12 \\
\hline & Mean & 9.07 & 8.48 & 9.17 & 3.32 & 3.00 & 3.43 & 27.40 & 25.51 & 28.15 & 15.91 & 15.05 & 16.19 \\
\hline & SD \pm & 1.92 & 0.84 & 1.55 & 0.63 & 0.29 & 3.57 & 5.67 & 2.53 & 3.82 & 3.12 & 1.14 & 0.53 \\
\hline
\end{tabular}

Table 4 shows the seasonal variations of the serum parameters (blood enzymes and hormones) of fish samples collected from the Damietta branch of the River Nile, Drain no.1 and Pumping Station during the investigation period. As shown in Table 4, there was a remarkable increase in mean G.S.H. and testosterone of males in RN (6.56 $\mathrm{mmol} / \mathrm{ml}$ and $9.90 \mathrm{ng} / \mathrm{ml}$, respectively) with a remarkable high value $(18.56 \mathrm{ng} / \mathrm{ml})$ in progesterone of females in RN, compared to the corresponding values in D1 and PS. On the other hand, a remarkable decrease was spotted in mean G.S.H., CAT, testosterone in males and progesterone of females in D1 $(2.42 \mathrm{mmol} / \mathrm{ml}, 1.61 \mathrm{U} / \mathrm{ml}, 4.06$ and 12.43 $\mathrm{ng} / \mathrm{ml}$, respectively) with a remarkable decrease in mean MDA $(49.36 \mathrm{nmol} / \mathrm{ml})$ of females in RN. 
Table (4): Seasonal variations in the serum parameters of the Oreochromis niloticus in the study sites.

\begin{tabular}{|c|c|c|c|c|c|c|c|c|c|c|c|c|c|}
\hline \multirow{3}{*}{ Sex } & \multirow{3}{*}{ Season } & \multicolumn{9}{|c|}{ Blood Enzymes } & \multirow{2}{*}{\multicolumn{3}{|c|}{$\begin{array}{c}\text { Blood Hormones } \\
\text { Testosterone (Males) } \\
\text { Progesterone (Females) } \\
(\mathrm{ng} / \mathrm{ml})\end{array}$}} \\
\hline & & \multicolumn{3}{|c|}{$\begin{array}{c}\text { GSH } \\
(\mathrm{mmol} / \mathrm{ml})\end{array}$} & \multicolumn{3}{|c|}{$\begin{array}{c}\text { CAT } \\
(\mathrm{U} / \mathrm{ml})\end{array}$} & \multicolumn{3}{|c|}{$\begin{array}{c}\text { MDA } \\
(\mathrm{nmol} / \mathrm{ml})\end{array}$} & & & \\
\hline & & $\mathbf{R N}$ & D1 & PS & $\mathbf{R N}$ & D1 & PS & RN & D1 & PS & $\mathbf{R N}$ & D1 & PS \\
\hline \multirow{6}{*}{$\sum_{\bar{\Sigma}}^{\frac{0}{\pi}}$} & Winter & 7.80 & 4.17 & 2.45 & 1.67 & 1.81 & 1.73 & 45.2 & 53.69 & 52.60 & 9.38 & 2.81 & 6.47 \\
\hline & Spring & 6.53 & 2.68 & 4.02 & 3.13 & 1.30 & 1.70 & 52.75 & 80.79 & 63.99 & 9.69 & 4.76 & 7.18 \\
\hline & Summer & 5.99 & 2.45 & 3.05 & 2.94 & 1.64 & 2.06 & 50.01 & 78.47 & 61.31 & 9.78 & 4.33 & 6.87 \\
\hline & Autumn & 5.94 & 3.17 & 4.62 & 2.78 & 1.68 & 2.56 & 54.51 & 78.00 & 57.83 & 10.76 & 4.35 & 8.26 \\
\hline & Mean & 6.56 & 3.12 & 3.54 & 2.63 & 1.61 & 2.01 & 50.62 & 72.74 & 58.93 & 9.90 & 4.06 & 7.20 \\
\hline & SD \pm & 0.86 & 0.76 & 0.97 & 0.66 & 0.22 & 0.40 & 4.06 & 12.76 & 4.92 & 0.60 & 0.86 & 0.77 \\
\hline \multirow{6}{*}{ 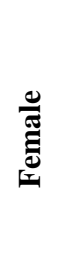 } & Winter & 5.54 & 2.31 & 2.65 & 1.85 & 1.62 & 1.50 & 46.6 & 73.44 & 60.6 & 16.26 & 10.71 & 12.63 \\
\hline & Spring & 6.42 & 2.62 & 5.01 & 2.88 & 1.88 & 2.56 & 50.93 & 82.13 & 64.11 & 19.13 & 12.71 & 15.96 \\
\hline & Summer & 5.45 & 2.03 & 4.00 & 2.84 & 1.84 & 2.52 & 51.34 & 71.61 & 63.78 & 18.71 & 13.32 & 15.83 \\
\hline & Autumn & 5.77 & 2.71 & 5.03 & 2.89 & 1.95 & 2.58 & 48.56 & 77.22 & 63.19 & 20.15 & 12.97 & 16.51 \\
\hline & Mean & 5.80 & 2.42 & 4.17 & 2.62 & 1.82 & 2.29 & 49.36 & 76.10 & 62.92 & 18.56 & 12.43 & 15.23 \\
\hline & SD \pm & 0.44 & 0.31 & 1.12 & 0.51 & 0.14 & 0.53 & 2.21 & 4.65 & 1.59 & 1.65 & 1.17 & 1.76 \\
\hline
\end{tabular}

Statistically, the one-way ANOVA test revealed that there was a very high significant difference of G.S.H. and testosterone in males and G.S.H., MDA and progesterone of females between different study sites $(\mathrm{p} \leq 0.001)$, and a high significant difference of MDA of males between different study sites $(p \leq 0.01)$, in addition to a significant difference of CAT of males between different study sites $(\mathrm{p} \leq 0.01)$, but there was no significant difference of CAT of females $O$. niloticus between different study sites ( $\mathrm{p}>0.05$ ). Multiple range comparisons (PostHoc tests: Tukey HSD) detected very high significant differences between RN and D1 ( $\mathrm{p} \leq 0.001)$ in G.S.H. and testosterone in males and G.S.H., MDA and progesterone of females, and very high significant differences between RN and PS $(\mathrm{p} \leq 0.001)$ in testosterone in males and MDA of females. On the other hand, Multiple range comparisons (PostHoc tests: Tukey HSD) detected highly significant differences of G.S.H. and testosterone in males and G.S.H of females between RN and PS and in MDA of males between RN and D1 and in testosterone in males between RN and PS $(\mathrm{p} \leq 0.01)$ and significant difference between RN and PS ( $\mathrm{p} \leq 0.05)$ in G.S.H. and Progesterone of females and between RN and D1 in CAT of males. Independent samples $t$-test indicated a non-significant difference of all hematological parameters between males and females $O$. niloticus except for blood hormones (Testosterone for males and Progesterone for females $(\mathrm{p}>0.05)$.

\section{Seasonal changes of monogenean ectoparasite, Cichlidogyrus halli}

The seasonal changes in the prevalence, mean intensity and abundance of Cichlidogyrus halli in gills of Oreochromis niloticus are shown in Table 5. 
Table (5). Seasonal changes in the prevalence (\%), mean intensity and abundance of gill ectoparasite, Cichlidogyrus halli of Oreochromis niloticus

\begin{tabular}{|c||c|c|c||c|c|c||c|c|c||}
\hline \multirow{2}{*}{ Season } & \multicolumn{3}{|c||}{ Prevalence values $(\%)$} & \multicolumn{3}{c||}{ Mean intensity values } & \multicolumn{2}{|c|}{ Abundance values } \\
\cline { 2 - 10 } & RN & D1 & PS & RN & D1 & PS & RN & D1 & PS \\
\hline \hline Winter & 80.0 & 92.0 & 96.0 & 3.7 & 5.0 & 4.0 & 2.9 & 4.6 & 3.9 \\
\hline Spring & 96.0 & 92.0 & 88.0 & 3.3 & 5.0 & 2.6 & 3.2 & 4.6 & 2.3 \\
\hline Summer & 100.0 & 100.0 & 96.0 & 2.6 & 9.9 & 6.7 & 2.6 & 9.9 & 6.4 \\
\hline Autumn & 80.0 & 92.0 & 76.0 & 3.1 & 5.1 & 3.7 & 2.4 & 4.7 & 2.8 \\
\hline Mean & 89.00 & 94.00 & 89.00 & 3.18 & 6.25 & 4.25 & 2.78 & 5.95 & 3.85 \\
\hline SD \pm & 10.52 & 4.00 & 9.45 & 0.46 & 2.43 & 1.74 & 0.35 & 2.63 & 1.83 \\
\hline \hline
\end{tabular}

The monogenean, $C$. halli attained its highest prevalence (100\%) in RN and D1 during the same season (summer); however, its lowest prevalence (76\%) was detected during autumn in PS. Additionally, the monogenean, $C$. halli showed its highest mean intensity (9.9) in D1 during summer and its lowest mean intensity (2.6) during summer in $\mathrm{RN}$ and spring in PS. Finally, $C$. halli, exhibited its highest abundance (9.9) in D1 during summer, however, its lowest abundance (2.3) was detected during spring in PS as shown in Table 5.

Statistically, the one-way ANOVA test revealed that there was a significant difference in prevalence, mean intensity and abundance of $C$. halli in $O$. niloticus between different study sites $(\mathrm{p} \leq 0.05)$. Multiple range comparisons (PostHoc tests: Tukey HSD) detected significant differences of prevalence, mean intensity and abundance between RN and PS and in MDA of males between RN and D1, and between $\mathrm{RN}$ and $\mathrm{PS}(\mathrm{p} \leq 0.05)$.

According to infestation levels in male and female of $O$. niloticus, Figure 3 exhibited the distribution of the mean prevalence of infection between the two sexes of $O$. niloticus. Concerning the sex of $O$. niloticus, the parasites recorded slightly higher mean prevalences in males that recorded $55.2 \%$ than in females that recorded $44.8 \%$. Statistically, the $t$-test revealed that there was a significant difference in prevalence between males and females of $O$. niloticus $(\mathrm{p} \leq 0.05)$.

The present study revealed the mean number of the monogenean Cichlidogyrus halli on different gills infesting O. niloticus. As shown in Figure 3, the mean number of the monogenean $C$. halli was the highest on the first right gill as well as on the first left gill of $O$. niloticus. The right gills generally recorded a higher infestation level of parasites than the left one. The highest mean number of the monogenean $C$. halli was recorded in the $1^{\text {st }}$ right gill, with mean number 1.87 parasites all over the investigation period, contrary to the $4^{\text {th }}$ right and left gills that recorded the lowest infestation level of parasites with a mean number 1.00 parasite during the investigation period. 


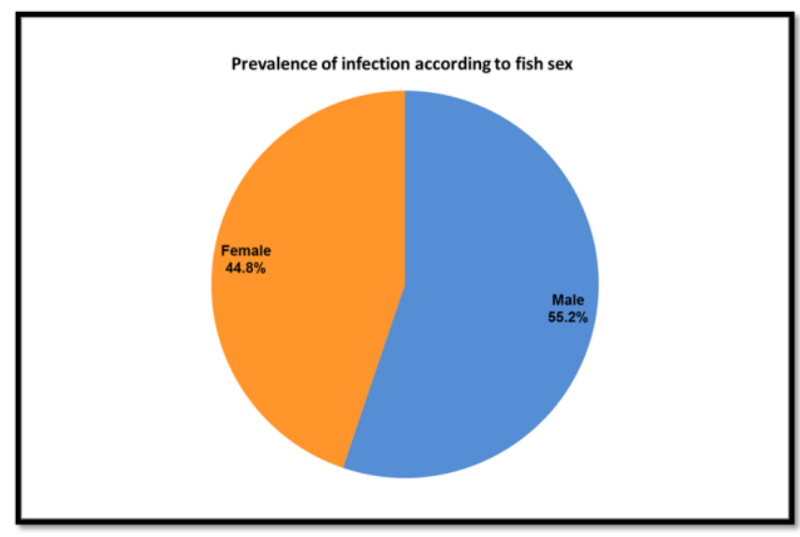

Figure (2). Mean prevalence of the parasites infesting different sex of Oreochromis niloticus.

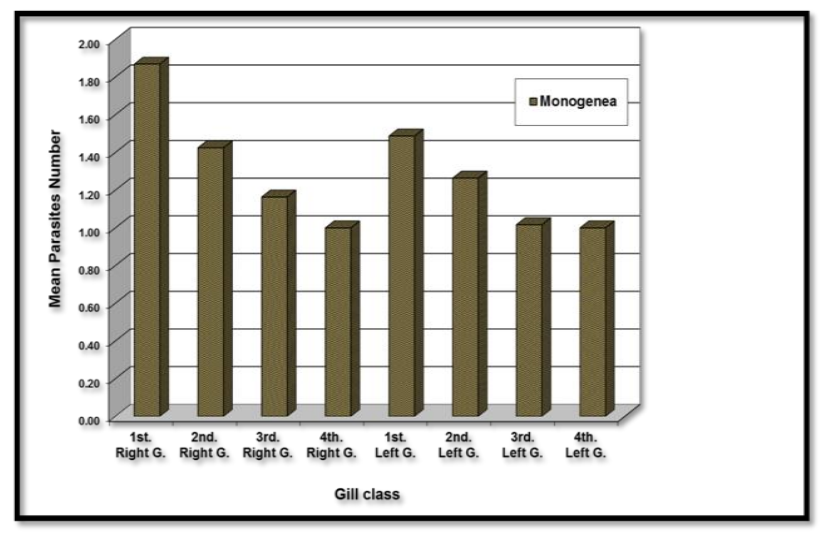

Figure (3). Mean number of the monogenean Cichlidogyrus halli on different gills infesting $O$. niloticus.

\section{Cluster and canonical corresponding analysis of the revealed data}

The cluster analysis program analyzes the input data of fish variables (condition factor, blood picture, hormones, enzymes, organic carbon and infestation level) of different study sites during the investigation period, then grouped them in a way where the high similarity index in water variables between each site type appears within the same group, while differential index variables separate them in two groups (A and B).

The application of cluster analysis based on the similarity in water variables (physical, chemical variables, condition factor, hematological analyses and infestation levels of $C$. halli of $O$. niloticus) of different study sites during the investigation period (3 variables) led to the recognition of two groups (Figures 4, 5, 6 and 7, respectively).

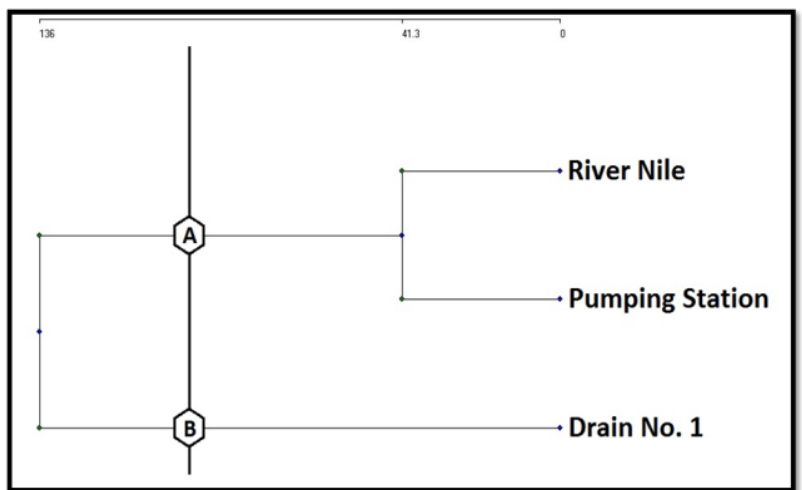

Figure (4). Cluster analysis of different study sites at different seasons according to physical and chemical water variables values of different study sites during the investigation period.

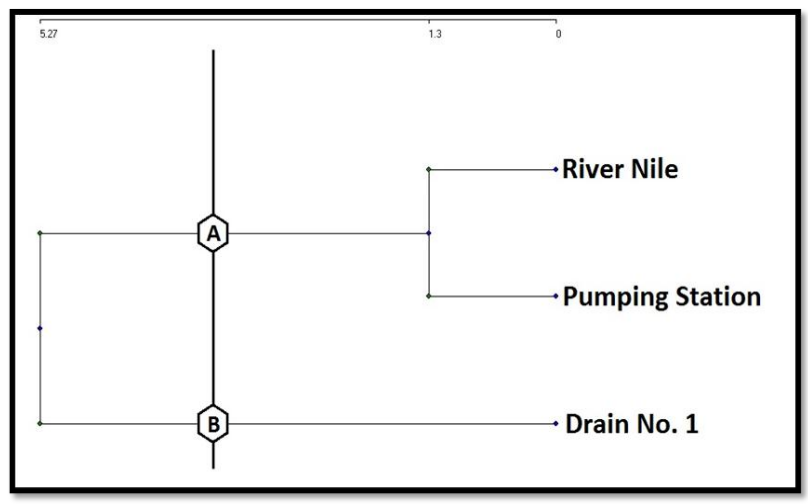

Figure (5). Cluster analysis of different study sites at different seasons according to condition factor variables values of $O$. niloticus during the investigation period. 


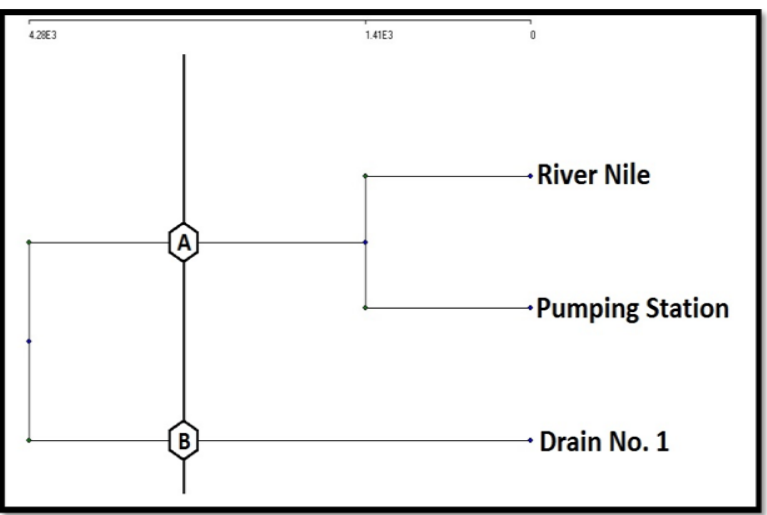

Figure (6). Cluster analysis of different study sites at different seasons according to blood analysis and variable values of $O$. niloticus during the investigation period.

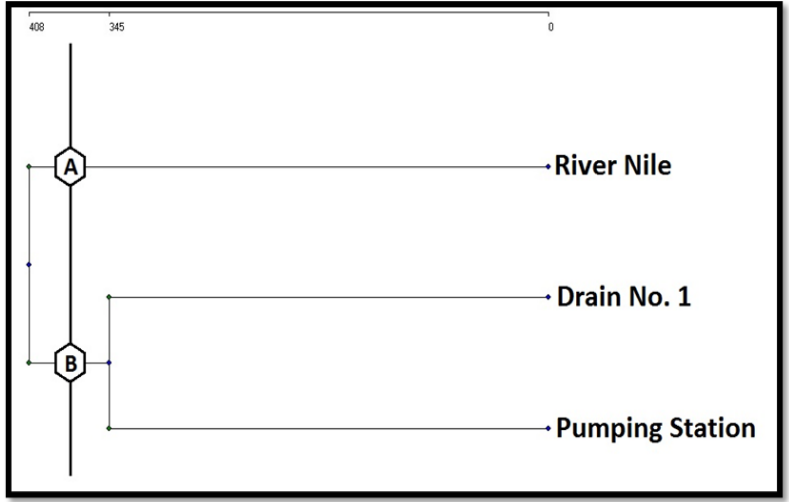

Figure (7). Cluster analysis of different study sites at different seasons according to infestation levels of monogenean parasite, Cichlidogyrus halli on different gills infesting $O$. niloticus during the investigation period.

According to water variables (physical and chemical variables), condition factor and hematological analysis of $O$. niloticus fish; Group A comprises two sites; RN and PS study sites. Group B comprises one site; D1.

This indicated that the similarity between RN and PS study sites in water variables (physical and chemical variables), condition factor and hematological analyses from D1 that showed in a separate group. Moreover, pumping station showed to be more similar to RN than D1 in water analyses, condition factor and hematological analyses of O. niloticus.

On the other hand, the application of cluster analysis based on the similarity in fish infestation levels of parasites led to the recognition of two groups (Figure 7). Group A comprises one site; RN study site. Group B comprises two sites; D1 and PS.

This indicated the similarity between D1 and PS study sites in fish infestation levels of parasites from RN that showed in a separate group. In addition, D1 showed to be more similar than PS to RN in fish infestation levels of parasites.

The Canonical Correspondence Analysis (CCA) program analyzes the input data of all water variables (physical and chemical parameters) for each site monthly, then detects the degree of different correlation between each blood analysis variable with the prevalence of parasites. The arrow length of each parameter represents the effective degree of this parameter. The correlation between water variables and infestation level of parasites (prevalence) in fish on the ordination diagram produced by Canonical Correspondence Analysis (CCA) is shown in Figure 8. 


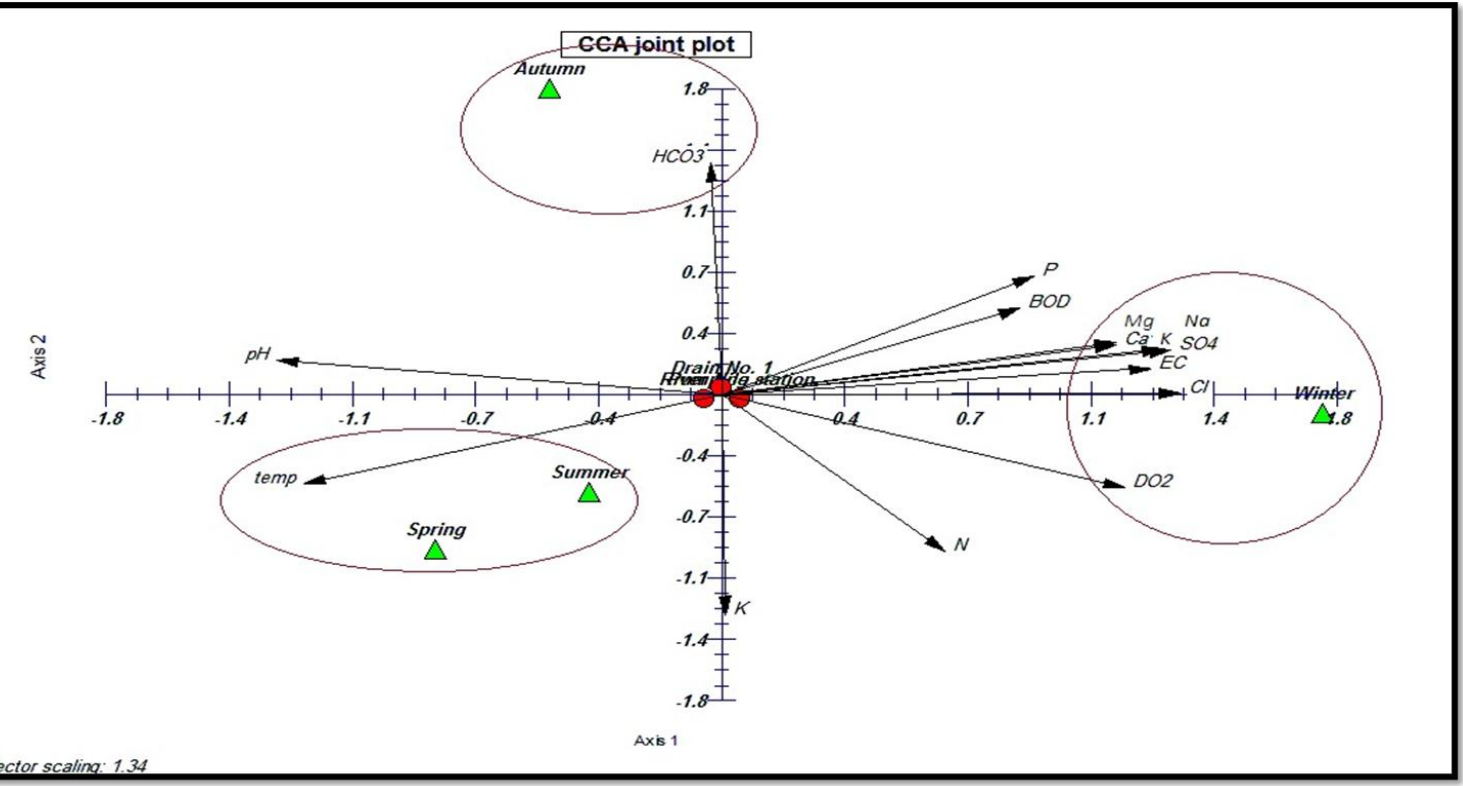

Figure (8). Canonical Corresponding Analysis (CCA) ordination diagram of the prevalence of parasites in Oreochromis niloticus according to the gradient of water physical and chemical parameters (arrows) during the investigation period in the study sites.

According to the prevalence of parasites, all physical and chemical water parameters showed a high significant effect on the prevalence of parasites in fish under investigation at the first and second axes. In addition, temperature appeared more effective in spring and summer seasons, while $\mathrm{HCO}_{3}$ in autumn and $\mathrm{Cl}, \mathrm{EC}, \mathrm{SO}_{4}, \mathrm{Na}, \mathrm{K}$, $\mathrm{Ca}, \mathrm{Mg}$ and $\mathrm{DO}_{2}$ showed to be more effective in the winter season. Furthermore, the appearance of all three study sites near the center indicated that these results were similar for the three study sites as shown in Figure 8.

In addition, the correlation between fish blood analyses (blood picture, enzymes and hormones) with infestation level of parasites (prevalence) in fish on the ordination diagram produced by Canonical Correspondence Analysis (CCA) is shown in Figure 9. It was found that all blood variables except for GSH hormone that showed a high significant effect on the prevalence of parasites in fish under investigation at the first and second axes. In addition, WBCs showed to be more effective in the spring and summer seasons and MCV, MCHC, MCH and GSH hormone showed to be more effective in the autumn season. Also, the appearance of all three study sites near the center indicated that these results were similar for the three study sites as shown in Figure 9. 


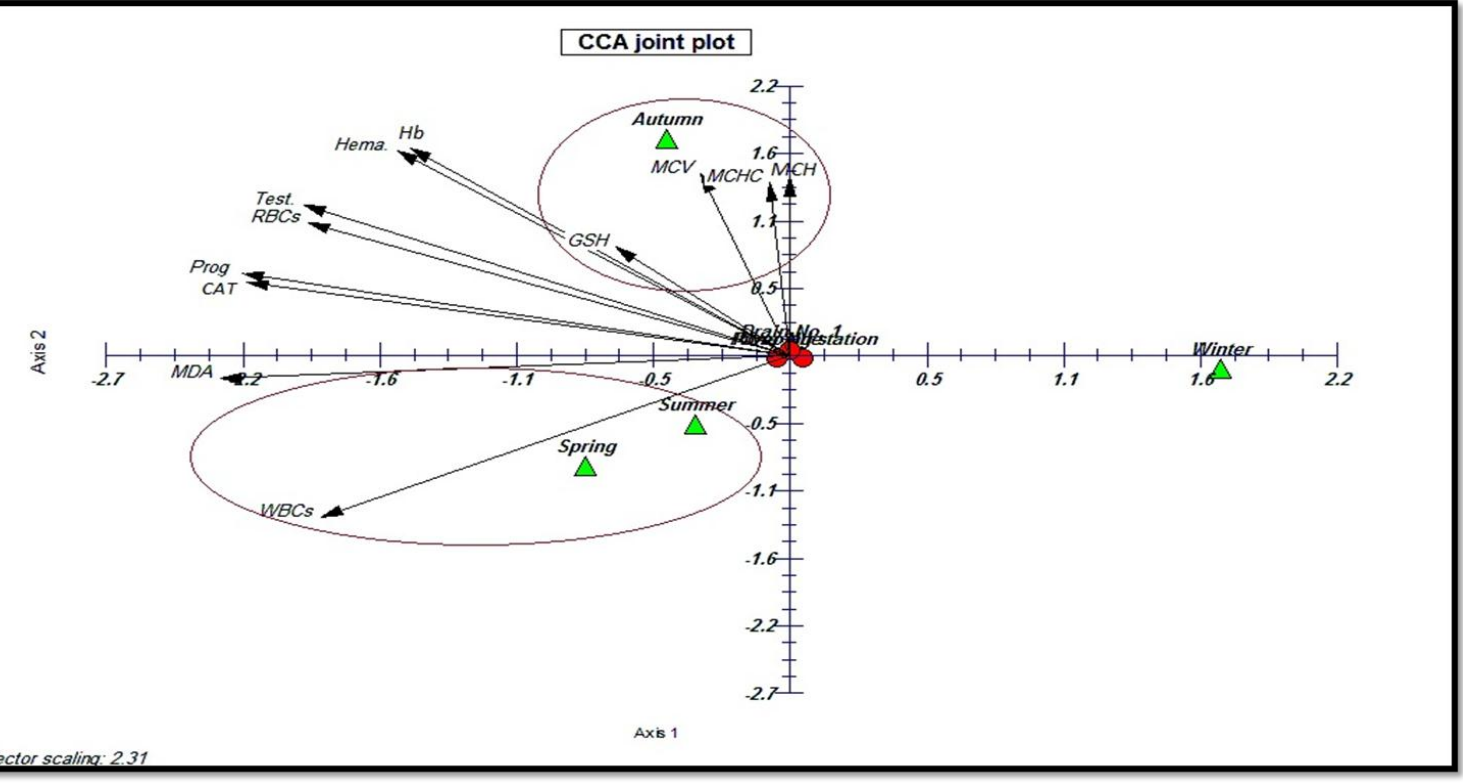

Figure (9). Canonical Corresponding Analysis (CCA) ordination diagram of the prevalence of parasites according to the gradient of blood analyses of Oreochromis niloticus (arrows) during the investigation period in the study sites.

\section{DISCUSSION}

Water is an important natural resource that is used for drinking and other developmental purposes in our life. Contamination of the aquatic environment, with a wide range of pollutants, has become a major concern over the past few decades (Bibi $\boldsymbol{e t}$ al., 2016). According to the World Health Organization (WHO, 1993), 80\% of diseases are waterborn. Drinking water in different countries does not meet WHO standards (Khan et al., 2013). About 3.1\% of deaths are caused by unsanitary water quality (Pawari \& Gawande, 2015). In the present study, all physical and chemical environmental parameters of the three different water bodies, as well as all parameters of blood analysis except for GSH hormone, showed a significant relationship with the prevalence of monogenean $C$. halli in the cichlid host fish $O$. niloticus according to Canonical Correspondence Analysis.

Hydrogen ion concentration is a highly important physicochemical parameter in defining the nature of water, Crane (2006) reported that highly acidic water with a $\mathrm{pH}$ of less than 5.5 limits fish growth and reproduction, noting that the ideal $\mathrm{pH}$ range for freshwater aquaculture should be between 6.5 and 7.0, although the $\mathrm{pH}$ range from 6.1 to 8.0 is also considered satisfactory for survival and reproduction of fishes.

Higher levels of dissolved oxygen (DO) were recorded in the River Nile (RN), however, Pumping Station (PS) and Drain No.1 (D1) was oxygen-poor. This agrees with the findings of Mashaly (2014) and El-Amier et al. (2015). Ross (2002) reported that the optimal growth of the tilapia DO is above $5 \mathrm{mg} / \mathrm{L}$. However, other researchers have demonstrated, tilapia can tolerate up to a high-oxygen supersaturated conditions to 40 
mg/L (Tsadik and Kutty, 1987). Upper and lower limits, Ross (2002) pointed out that the DO concentration of $3 \mathrm{mg} / \mathrm{L}$ should be the minimum for optimal growth of tilapia. Feeding strategies that do not consider oxygen levels in the water can result in large amounts of uneaten forage with negative consequences for both the environment and the profitability of aquaculture production (Obirikorang et al., 2020).

Biochemical oxygen demand (BOD) represents the amount of oxygen that bacteria and other microorganisms consume during their decomposition of organic matter under aerobic conditions (oxygen is present) at a specified temperature. The present study indicated that there was an increase in BOD from the permissible limits $(6 \mathrm{mg} / \mathrm{L})$ of WHO (1993) and the value of Egyptian law (48/1982), which reached $6.3 \mathrm{mg} / \mathrm{L}$ in RN and $6.4 \mathrm{mg} / \mathrm{L}$ in the PS. According to Al-Afify (2010) efficiently treated sewage would have a BOD value of about $20 \mathrm{mg} / \mathrm{L}$.

Difference in values of prevalence, mean intensity and abundance of ectoparasites between RN, D1 and PS in the present investigation may be related to the different response to different salinities at the sites under study that agreed with Nie and Kennedy (1991) and Shawket et al. (2018) who suggested that salinity influences the prevalence and intensity of adult monogeneans.

Hematology research is a tool that investigate physiological changes caused by environmental pollution (Zaghloul, 2001; Zaghloul et al., 2005). Hematological parameters, such as the number of hematocrit, hemoglobin, WBC and RBC are an application for wide potential toxicity index for toxicity studies and environmental monitoring in aquatic animals (Sancho et al., 2000; Barcellos et al., 2003). Knowledge of the characteristics of blood can be used as an effective and sensitive index monitoring fish physiological and pathological changes (Kim \& Kang, 2017). An important tool for diagnosing health, with varying degrees of blood response of fish and according to different stress factors, is stimulation and treatment of parasitic or infectious diseases (Rehulka, 2002; Chen et al., 2004; Martins et al., 2004; Silveira-Coffigny et al., 2004).

Hematological parameters are indicator of water balance, nutritional status and general health of fish (Chang \& Hur, 1999; Denson et al., 2003). Therefore, hematological variables have been used as indicators of the health status of fish in a number of fish species to detect physiological changes due to stress, such as exposure to pollutants, hypoxia, transport, anesthesia and acclimatization (Akinrotimi, 2009).

In the present study, there was no significant difference in hemoglobin of male or female $O$. niloticus between different study sites. Essam et al. (2002) reported the average of hemoglobin of a catfish blood sample is 14.7 to $1.2 \mathrm{~g} / \mathrm{dl}$. On the other hand, the results obtained agreed with those of the average reported by Mohammed (1999) who stated that hemoglobin concentration is in the range of 5.27- to $9.7 \mathrm{gm} / 100 \mathrm{ml}$ of blood fish samples collected from different locations in Egypt. Singh et al. (2008) suggested that different water pollutants are the possible radical source of the physiological disorders of fish. 
In the current study, the one-way ANOVA test revealed that there was no significant difference in all blood picture parameters (Hemoglobin, RBCs, HCT and WBCs) of male and female $O$. niloticus between different study sites. Vinodhini and Narayanan (2009) reported that there was a significant reduction in RBCs of freshwater fish exposed to heavy metals, which disagreed with the present study. According to Martins et al. (2008), low red blood cells and hematocrit counts indicated that red blood cells are affected or destroyed by infection. The present results showed that hematocrit ranged from 21\% to 34\% which agreed with Ayandiran et al. (2010) who said normal hematocrit values typically fall in the range of $20-35 \%$ and are rarely more than $50 \%$ of fish.

Parasites are important components of societies and make up a large part of the biodiversity found in ecosystems, providing valuable information about their hosts and the environment in which they live. Most parasite species rarely cause problems in the natural environment but in aquaculture, parasites often cause serious outbreaks of disease (Roberts, 2012). They play an important role in determining the productivity, sustainability and economic viability of aquaculture. Parasite infections cause serious socio-economic, ecological and welfare consequences in global finfish aquaculture (Menezes et al., 1990; Barber, 2007; Shinn et al., 2015). They are common in fish gills and skin. However, some monogenean species invade the rectal cavity, the ureter, the body cavity, nose, intestine, stomach and even vascular system (Rohde $\boldsymbol{e t}$ al., 1992; Pariselle \& Euzet, 1998; Whittington et al., 2000). Monogenic parasites are ectoparasites that often present high host specificity (Goater $\boldsymbol{e t}$ al., 2014). Fishes are the main hosts for most monogenean organisms and a few of the aquatic invertebrates (Whittington, 1998; Lerssutthichawal \& Lim, 2005; Peggy et al., 2012). Furthermore, the parasite is free to move around the surface of the body of the fish, mucus and epithelial cells of gill feeding; however, some adult monogenean will remain permanently attached to a single site on the host (Peggy et al., 2012). The environmental factors such as water temperature, play a significant role in the change of seasons. Temperature is the most important abiotic factors possible to affect population dynamics of monogeneans (Lambert, 1990; Xenopoulos et al., 2005). Monogenic organisms feed on the host material that can be absorbed and used to produce eggs or larvae (Kurt \& Lindenstrøm, 2002). Association with certain parasitic infections may provide improvement in fish productivity; as the presence of different parasite species depends on many factors such as the life stages of the parasite, the current number of host species, age, water temperature and other environmental conditions (El-Naggar, 1999).

El-Naggar (1999) revealed that the monogenean Cichlidogyrus halli is highly specific to the cichlid host fish Oreochromis niloticus, and was considered a satellite species on the gills of $O$. niloticus. In the investigated study, a survey has been done and a detailed account has been given of the seasonal changes in the prevalence, mean intensity and abundance of the monogenean gill parasites of cichlid host fish Oreochromis niloticus in three study sites: RN, D1 and PS.

It was found that the prevalence of Cichlidogyrus halli exhibited maximum values in $O$. niloticus in $\mathrm{RN}$ and $\mathrm{D} 1$ during summer. On the other hand, its lowest prevalence was detected during autumn in the PS. Moreover, the mean intensity of $C$. halli showed maximum values in O. niloticus in D1 during summer. On the other hand, its minimum values were detected during the summer in $\mathrm{RN}$ and spring in PS. 
Additionally, an abundance of $C$. halli, exhibited its highest abundance that was detected in D1 during summer, however, its lowest abundance was detected during spring in PS. The present results were concordant with El-Naggar (1999) who indicated that many monogeneans of $O$. niloticus exhibited their highest prevalence, mean intensity and abundance in summer. Additionally, results were in agreement with Koyun and Altunel (2011) who stated that the prevalence and mean intensity levels of monogeneans (Dactylogyrus anchoratus and Gyrodactylus katharineri) infesting Carassius carassius were higher during spring and summer. Edward et al. (1965) found that fish can produce an immune response at temperatures from 5 to $8^{\circ} \mathrm{C}$. Godoy et al. (2011) stated that the host immunity may lead parasites to migrate for escaping from localized immune responses induced by infection. If the water temperature is too high, the immune response may be decreased and the fish is more susceptible to parasites (Meyer, 1970).

In the present study, the comparison between males and females showed significant differences as males were more parasitized than females, yet the levels of parasitism among males were lower than females in general which coincided with (Rohde, 1984). The difference in infection between the sexes of the host species is less common (Mashaly, 2014).

The results showed that the percentage of occurrence of the monogenean $C$. halli was highest on the first right gill as well as on the first left gill of $O$. niloticus. Whereas the percentage of occurrence showed mainly a gradual decrease in the second and third right and left gills, showing the lowest percentage of occurrence on the fourth right and left gills of the fish. The present results agreed with El-Naggar (1999) who indicated that the distribution of cichlidogyrid monogeneans on the gills of O. niloticus and T. zilli was non-random. Most of these monogeneans showed a gradual decline in their percentage distribution from the first to the fourth gill arch with a higher preference for the first two gill arches. Similarly, Agos (2013), Madanire-Moyo et al. (2011) and Tombi et al. (2014) also reported that there was no significant difference in the preferences of monogeneans on both branchial sides of Oreochromis spp.. According to Rohde (1993), the parasite's preferences for a specific location of the host may be related to the body symmetry of the parasites. Lim et al. (2016) found that the first and other three gills were predominantly affected by all types of monogenean in gills, except for the monogeneans in the wild $O$. niloticus which were randomly distributed among the four pairs of gill arches. Some researchers suggested that the higher preferences of parasites over the second and third intermediate arches are due to two main factors: respiratory water currents and the surface area of the gills (Paling, 1968; Gutiérrez \& Martorelli, 1999). Fryer and Iles (1972) found a difference in the morphology between the first gill and other gills of the same cichlid host, and this has led El-Naggar and Khidr (1986) to suggest that the distribution of cichlidogyrids on cichlid fish hosts is affected by the morphological differences between the gills.

\section{CONCLUSION}

According to physical and chemical analyses, River Nile and Pumping Station showed a significant similarity in the physical and chemical water variables. Whereas, hematological analyses revealed that the River Nile and Pumping Station showed a significant similarity in the hematological analysis of Oreochromis niloticus. Moreover, 
parasitological analysis concluded that the River Nile and Drain No.1 showed a significant similarity in the parasitological infestation levels in O. niloticus.

In conclusion, the difference in environmental characteristics, despite the stability of the geographical location, led to the emergence of differences in blood analysis of fish and infestation level of parasites in the study sites, which confirms the evidence of using fish and parasites as biological biomarkers to assess their environment.

\section{REFERENCES}

Agos, S. (2013). A Study of Monogenean Gill Parasite on Cage Cultured Red Tilapia (Oreochromis sp.) in Relation to Water Physico-chemical Parameters in Como River, Kenyir Lake. M.Sc. thesis, University Malaysia Terengganu.

Akinrotimi, O. A. (2009). Effects of acute stress on haematological parameters of Tilapia guineensis. J Nonlinear Sci, 5(4): 338-343.

Al-Afify, A. D. G. (2010). Biochemical and Ecological Studies on El-Serw Fish Farm. Ph.D. Thesis, Faculty of Agriculture, Cairo University, Egypt.

Alrumman, S. A.; El-kott, A. F. and Kehsk, M. A. (2016). Water pollution: Source and treatment. J. Environ. Eng., 6(3): 88-98.

Ayandiran, T. A.; Fawole, O. O.; Adewoye, S. O. and Ogundiran, M. A. (2010). Bioconcentration of metals in the head capsule and skeleton of Clarias gariepinus exposed to sublethal concentrations of soap and detergent effluents. ABJNA, 1(3): $330-342$.

Barber, I. (2007). Parasites, behaviour and welfare in fish. Appl. Anim. Behav. Sci., 104: 251-264.

Barbieri, E.; Ruíz-Hidalgo, K.; Rezende, K. F. O.; Leonardo, A. F. G. and Sabino, F. P. (2017). Efectos del carbofuran en juveniles de Oreochromis niloticus en la toxicidad, metabolismo de rutina y los parámetros hematológicos. Bol. Inst. Pesca, 43(4): 513-526. http:// dx.doi.org//10.20950/1678-2305.2017v43n4p513

Barcellos, L. J. G.; Kreutz, L. C.; Rodrigues, L. B.; Fioreze, I.; Quevedo, R. M.; Cericato, L.; Conrad, J.; Soso, A. B.; Fagundes, M.; Lacerda, L. A. and Terra, S. (2003). Haematological and biochemical characteristics of male Jundiá (Rhamdia Quelen, Quoy \& Gaima RDT, Pimelodidae): changes after acute stress. Aquac. Res., 34: $1465-1469$.

Bergquist, C.; Nillius, S. J. and Wide, L. (1983). Human gonadotropin therapy: 1. Serum estradiol and progesterone patterns during conceptual cycles. Fertil. Steril., 39: 761-765.

Beutler, E.; Duron, O. and Kellin, B. M. (1963). Improved method for the determination of blood glutathione. J Lab Clin Med, 61: 882-888. 
Bibi, S.; Khan, R. L. and Nazir, R. (2016). Heavy metals in drinking water of Lakki Marwat District, KPK, Pakistan. World Appl. Sci. J., 34(1): 15-19.

Bosisio, F.; Rezende, K. F. O. and Barbieri, E. (2017). Alterations in the hematological parameters of Juvenile Nile Tilapia (Oreochromis niloticus) submitted to different salinities. Pan-Am. j. aquat. sci., 12(2): 146-154.

Briggs D. (2003). Environmental pollution and the global burden of disease. Br. Med. Bull., 68: 1-24.

Chang, Y. J. and Hur, J. W. (1999). Physiological responses of grey mullet Mugil cephalus and Nile tilapia Oreochromis niloticus by rapid changes in salinity of rearing water. J Korean Soc Fish Ocean Technol, 32(3): 310-316.

Chen, C. Y.; Wooster, G. A. and Bowser, P. R. (2004). Comparative blood chemistry and histopathology of tilapia infected with Vibrio vulnificus or Streptococcus iniae or exposed to carbon tetrachloride, gentamicin, or copper sulphate. Aquaculture, 239(4): 421-443

Cohen, G.; Dembiec, D. and Marcus, J. (1970). Measurement of catalase activity in tissue. Anal. Biochem, (34): 30-38.

Crane, B. (2006). Results of Water Quality Measurements in Messer Pond. Water Sampling Summary, pp. 1-9.

Crovello, T. J. (1970). Analysis of haracters variation in ecology and systematics. Annu Rev Ecol Evol Syst, 1: 55-98.

Dacie, J. V. and lewis, S. M. (1977). Practical Haematology. 5th Ed. Churchill Livingstone. London, 297pp.

Denson, M.; Stuart, K. R.; Smith, T. J.; Charles, R.; Weirlch, Al. and Segars, L. (2003). Effects of salinity on growth, survival and selected haematological parameters of juvenile cosia Rachycentron canadum. J World Aquac Soc, 34: 496-504.

Drabkin, D. L. (1946). Thermodynamics of anti-sickling agents with hemoglobin S. Journal of Biological Chemistry, 164: 703-723.

Edward, E. E.; Kent, S. P.; Attleberger, M. H.; Seibert, C.; Bryant, R. E. and Booth, B. (1965). Antibody synthesis in poikilothermic vertebrates. Ann. N. Y. Acad. Sci, 126(1): 629-649.

El-Amier, Y. A.; Zahran, M. A. and Al-Mamoori, S. O. (2015). Assessment the physico-chemical characteristics of water and sediment in Rosetta Branch, Egypt. JWARP, 7: 1075-1086.

Elgohary, I.; Abd Elatief, J. I.; Fadel، N. G.; Eissa, A. E. and Mahmoud, M. A. (2020). Pathological, bacteriological and seasonal prevalence of Aeromonas 
hydrophila، Vibrio vulnificus, Proteus vulgaris and Pseudomonas aeruginosa; infecting Oreochromis niloticus in some Egyptian fish farms. Egypt. J. Aquat. Biol. Fish., 24(5): 467 - 482.

El-Naggar, A. M. A. (1999). Comparative Ecological Studies on the Monogenean Gill Parasites of the Cichlid Fishes Oreochromis niloticus and Tilapia Zillii inhabiting Manzala Lake and the River Nile in Egypt. Ph.D. Thesis, Faculty of Science, Mansoura University, Egypt.

El-Naggar, M. M. and Khidr, A. A. (1986). Micro-ecology of some cichlidogyrid monogeneans from the gills of two Tilapia spp. from Damietta branch of the River Nile in Egypt. Proc. Zool. Soc. Arab Repub. Egypt, 12: 263-274.

Essam, S. A.; Abbas, A. Y. and Mohammed, N. M. (2002). Effect of water temperature upon the response of cultured Clarias lazera to saprolegnia infection and the consequent haematological changes. J. Egypt. Com. Path. \& Clinic. Path, 15(2): 108125 .

Fazio, F. (2019). Fish hematology analysis as an important tool of aquaculture: A review. Aquaculture, 500(1): 237-242.

Fryer, G. and Iles, T. D. (1972). The Cichlid Fishes of the Great Lakes of Africa: Their Biology and Evolution. Oliver \& Boyd, Edinburgh.

GAFRD (2007). Annual report for country fish production in 2007. The general authority for fishery resources development: summary production statistics Cairo, Egypt.

Goater, T. M.; Goater, C. P. and Eech, G. W. (2014). Parasitism: The Diversity and Ecology of Animal Parasites. Cambridge, Cambridge University Press, 497pp.

Godoy, M. R.; Cordova, G. M.; Lugo, M. G.; Ulloa, M. S. and Vidal, G. M. (2011). Microhabitat use, not temperature, regulates intensity of Gyrodactylus cichlidarum long-term infection on farmed tilapia-Are parasites evading competition or immunity? Vet. Parasitol., 20: 1-12.

Gutiérrez, P. A. and Martorelli, S. R. (1999). Hemibranch preference by freshwater monogeneans a function of gill area, water current, or both?. Folia Parasitol., 46: 263266.

Hesser, E. F. (1960). Methods for routine fish hematology. Prog. fish-cult., 22(4): 164171.

Khan, N.; Hussain, S.T. and Saboor, A. (2013). Physiochemical investigation of the drinking water sources from Mardan, Khyber Pakhtunkhwa, Pakistan. IJPS, 8(33): 1661-1671.

Khan, R. A. and Payne, J. F. (2004). Comparative study of oil well drill cuttings and polycyclic aromatic hydrocarbons on parasitism in winter flounder: A dose-response study. Bull Environ Contam Toxicol, 73: 652-658. 
Khan, R. A. and Thulin, J. (1991). Influence of pollution on parasites of aquatic animals. Adv. Parasitol., 30: 201-238.

Kim, J. and Kang, J. (2017). Toxic effects on bioaccumulation and hematological parameters of juvenile rockfish Sebastes schlegelii exposed to dietary lead $(\mathrm{Pb})$ and ascorbic acid. Chemosphere, 176: 131-140.

Koyun, M. and Altunel, F. N. (2011). Prevalence of two monogenean parasites on different length groups of Crucian carp (Carassius carassius Linnaeus, 1758). Not. Sci. Biol., 3(1): 17-21.

Kurt, B. and Lindenstrøm, T. (2002). Interactions between monogenean parasites and their fish hosts. Int J Parasitol, 32: 309-319.

Lambert, A. (1990). Environment and host-parasite relationships in monogenea. Folia Parasitol., 37: 219-224.

Lerssutthichawal, T. and Lim, L. H. S. (2005). Diversity of freshwater monogeneans from Siluriformes fishes of Thailand. In: Walker, P., Lester, R., Bondad-Reantaso, M.G. (Eds.), Diseases in Asian Aquaculture. Health Section V. Fish. Asian Fisheries Society, Manila, 225pp.

Lim, S. Y.; Ooi, A. L. and Wong, W. L. (2016). Gill monogeneans of Nile tilapia (Oreochromis niloticus) and red hybrid tilapia (Oreochromis spp.) from the wild and fish farms in Perak, Malaysia: infection dynamics and spatial distribution. Springerplus, 5(1): 1609.

Mackenzie, K. (1999). Parasites as pollution indicators in marine eco-systems: A proposed early warning system. Mar. Pollut. Bull, 38: 955-959.

Madanire-Moyo, G. N.; Matla, M. M.; Olivier, P. A. and Luus-Powell, W. J. (2011). Population dynamics and spatial distribution of monogeneans on the gills of Oreochromis mossambicus (Peters, 1852) from two lakes of the Limpopo River System, South Africa. J. Helminthol, 85: 146-152.

Marcogliese, D. J. (2005). Parasites of the superorganism: Are they indicators of ecosystem health?. Int J Parasitol, 35: 705-716.

Marcogliese, D. J.; Nagler, J. J. and Cyr, D. G. (1998). Effects of exposure tocontaminated sediments on the parasite fauna of American plaice (Hipoglossoides platessoides). Bull Environ Contam Toxicol, 61: 88-95.

Margolis, L.; Esch, G. W.; Holmes, J.; Holmes, J. C.; Kuris, A. M. and Schad, G. A. (1982). The use of ecological terms in parasitology. J. Parasitol, 68: 131-33.

Martins, M. L.; Mouriño, J. L. P.; Amaral, G. V.; Vieira, F. N.; Dotta, G.; Jatobá, A. M. B.; Pedrotti, F. S.; Jerônimo, G. T.; Buglione-Neto, C. C. and Pereira-Jr, G. 
(2008). Haematological changes in Nile tilapia experimentally infected with Enterococcus sp. Braz. J. Biol., 68(3): 657-661.

Martins, M. L.; Tavares-dias, M.; Fujimoto, R. Y.; Onaka, E. M. and Nomura, D. T. (2004). Haematological alterations of Leporinus macrocephalus (Osteichthyes: Anostomidae) naturally infected by Goezia leporini (Nematoda: Anisakidae) in fish pond. Arq Bras Med Vet Zootec, 56(5): 640-646.

Mashaly, M. I. (2014). Ecological Impacts on Biodiversity of Helminth Parasites on Certain Cichlid and Clariid Fish in Different Localities at River Nile and Lake Manzala in Egypt, Ph.D. Thesis, Faculty of Science, Mansoura University, Egypt.

Matthiessen, P. (2003). Endocrine disruption in marine fish. Pure Appl. Chem., 75: 1112.

Menezes, J.; Ramos, M. A.; Pereira, T. G. and Moreira da Silva, A. (1990). Rainbow trout culture failure in a small lake as a result of massive parasitosis related to careless introductions. Aquaculture, 89: 123-126.

Meyer, F. P. (1970). Seasonal fluctuations in the incidence of disease on fish farms. In A symposium on diseases of fishes and shellfishes, S. F. Snieszko (ed.). American Fisheries Society Special Publication Number 5, pp. 29.

Mohammed, A. H. I. (1999). Biochemical studies on the Effect of Pollution on the Fish Production in Dakhlia and Damietta." M. Sc, Thesis, Faculty of Agriculture, Mansoura University, Egypt.

Moles, A. and Wade, T. L. (2001). Parasitism and phagogytic function among sand lance Ammodytes hexapterus Pallas exposed to crude oil-laden sediments. Bull Environ Contam Toxicol, 66: 528-535.

Nie, P. and Kennedy, C. R. (1991). Occurrence and seasonal dynamics of Pseudodactylogyrus anguillae (Yin \& Sproston) (Monogenea) in eel, Anguilla anguilla (L.), in England. J. Fish Biol, 39: 897-900.

Obirikoranga, K. A.; Acheamponga, J. N.; Duodua, C. P. and Skov, P. V. (2020). Growth, metabolism and respiration in Nile tilapia (Oreochromis niloticus) exposed to chronic or periodic hypoxia. Comparative Biochemistry and Physiology, Part A, 248: 110768 .

Paling, J. E. (1968). A method of estimating the ventilative volumes of water flowing over the different gills of a freshwater fish. J. Exp. Biol., 48: 533-544.

Paperna, I. (1960). Studies on monogenetic trematodes in Israel. 2 Monogenetic trematodes of cichlids. Isr J Aquac, 12: 20-33. 
Pariselle, A. and Euzet, L. (1998). Five new species of Cichlidogyrus (Monogenea: Ancyrocephalidae) from Tilapia brevimanus, T. buttikoferi and T. cessiana from Guinea, Ivory Coast and Sierra Leone (West Africa). Folia Parasitol., 45: 275-282.

Pawari, M. J. and Gawande, S. (2015). Ground water pollution \& its consequence. IJERGS, 3(4): 773-776.

Peggy, R.; Ruth, F. F.; RuthEllen, K., Denise, P. (2012). Monogenean Parasites of Fish, Institute of Food and Agricultural Sciences. UFL, 8: 1-10.

Ranzani-Paiva, M. J. T.; Rodrigues, M. L.; Veiga, A. C. and Eiras, B. E. S. (2003). Differential leukocyte counts in "dourado" Salminus maxillosus Valenciennes, 1840 from the Mogi-Guaçu River, Pirassununga, SP. Braz. J. Biol., 63: 517-25.

Rehulka, J. (2002). Aeromonas causes severe skin lesions in rainbow trout (Oncorhynchus mykiss): clinical pathology, haematology and biochemistry. Acta Vet Brno, 71(3): 351-360.

Roberts, R. J. (2012). The Parasitology of Teleosts. In: Fish Pathology, Fourth Edition. Blackwell Publishing Ltd.

Rohde K (1984). Ecology of marine parasites. Helgoländer Meeresun, 37: 5-33.

Rohde, K. (1993). Ecology of marine parasites. CAB International, Wallingford Rózsa L, Reiczigel J, Majoros G (2000) Quantifying parasites in samples of hosts. J. Parasitol, 862: 228-232.

Rohde, K.; Heap, M.; Hayward, C. J. and Graham, K. J. (1992). Calitotyle australiensisn sp. and Calitotyle sp. (Monogenea, Monopisthocotylea) from the rectum and rectal glands of Rugogaster hycholagi Shell, 1973 (Trematoda, Apisdogastrea from the rectal glands of holocephalans off the coast of southeastern Autralia. Syst. Parasitol., 21: 69-77.

Ross, L. L. (2002). Environmental physiology and energetic. Fish Fish (Oxf)., 25: 89128.

Sancho, E.; Cerón, J. J. and Ferrando, M. D. (2000). Cholinesterase activity and hematological parameters as biomarkers of sublethal molinate exposure in Anguilla anguilla. Ecotoxicol. Environ. Saf., 46: 81-86.

Satoh, K. (1978). Serum lipid peroxide in cerebrospinal disorder determined by a new colorimetric method. Clin. Chim. Acta, 90: 37-43.

Sayed, A. H.; Abd Allah, E. A.; Hamed, M. and Soliman, H. A. M. (2020). Hepatonephrotoxicity in late juvenile of Oreochromis niloticus exposed to gibberellic acid: Ameliorative effect of Spirulina platensis. Pestic Biochem Physiol, 167: 104600. 
Shaw, A. F. (1930). A direct method for counting the leucocytes, thrombocytes and erythrocytes of birds blood. J. Pathol., 33: 833-835.

Shawketa, N.; Elmadhia, Y.; Mbarecka, I.; Youssira, S.; El Kharrima, K. and Belghyti, D. (2018). Distribution of two monogenean (Gastrocotylidae) from the North Atlantic coast of Morocco. BJBAS, 7: 270-275.

Shinn, A. P.; Pratoomyot, J.; Bron, J. E.; Paladini, G.; Brooker, E. E. and Brooker, A. J. (2015). Economic costs of protistan and metazoan parasites to global mariculture. Parasitology, 142: 196-270.

Silveira-coffigny, R.; Prieto-trujillo, A. and Ascencio-valle, F. (2004). Effects of different stressors in haematological variables in cultured Oreochromis aureus S. Comp Biochem Physiol C Toxicol Pharmacol, 139(4): 245-250.

Singh, D.; Nath, K.; Trivedi, S. P. and Sharma, Y. K. (2008). Impact of copper on haematological profile of freshwater fish, Channa punctatus. J. Environ. Biol, 29: 253257.

Snieszko, S. F. (1960). Microhematocrit as a Tool in Fishery Research and Management. Washington, pp. 15.

Tavares-Dias, M. and Moraes, F.R. (2004). Hematologia de peixes teleósteos. Ribeirão Preto, Villimpress Complexo Gráfio, pp. 144.

Tayel, S. I.; Ahmed N. A. and Ramadan, E. A. (2020). Histopathological alterations and parasitic infection in Oreochromis niloticus fish inhabiting the River Nile water. Egypt. J. Aquat. Biol. Fish., 24(1): 233 - 247.

ter-Braak, C. J. (1986). Canonical correspondence analysis: A new eigenvector technique for multivariate direct gradient analysis. Ecology, 67: 1167-1179.

ter-Braak, C. J. (1988). CANOCO-aFORTRAN Program for canonical community ordination by partial detrended correspondence analysis, principal. Component Analysis and Redunancy Analysis (Version 2.1). Agric. Math. Group, Wageninigen, The Netherlands.

Tombi, J.; Akoumba, J. F. and Bilong, C. F. B. (2014). The monogenean community on the gills of Oreochromis niloticus from Melen fish station in Yaounde, Cameroon. Int. J. Bus. Res., 2: 16-23.

Trewavas, E. (1983). Tilapiines fishes of the genera Sarotherodon, Oreochromis and Danakilia. British Museum (Natural History), London.

Tsadik, G. G. and Kutty, M. N. (1987). Influence of ambient oxygen on feeding and growth of the tilapia, Oreochromis niloticus (Linnaeus) ARAC/87/WP/10. Nigeria: Port Harcourt, 16pp.

Val, A. L.; Paula-Silva, M. N.; Almeida-Val, V. M. F. and Wood, C. M. (2016). In vitro effects of increased temperature and decreased $\mathrm{pH}$ on blood oxygen affinity of 10 fish species of the Amazon. J. Fish Biol, 81(1): 264-279. 
Vinodhini, R. and Narayanan, M. (2009).The impact of toxic heavy metals on the hematological parameters in common carp (Cyprinus carpio L.). J. Environ. Health Sci. Eng., 6(1): 23-28.

Whittington, I. D. (1998). Diversity down under: monogeneans in the antipodes Australia with a prediction of monogenean biodiversity worldwide. Int J Parasitol, 28: 1481-1493.

Whittington, I. D.; Cribb, B. W.; Hamwood, T. E. and Halliday, J. A. (2000). Hostspecificity of monogenean (Platyhelminth) parasites: a role for anterior adhesive areas?. Int J Parasitol, 30: 305-320.

WHO (1993). Guidelines for Technologies for Water Supply Systems in Small Communities. World Health Organization, Geneva.

Xenopoulos, M. A.; Lodge, D. M. and Alcamow, J. (2005). Scenarios of freshwater fish extinctions from climate change and water with-drawal Glob. Chem. Biol., 11: 1557-1564.

Yamaguti, S. (1963). Systema Helminthum. Vol. IV. Monogenea and Aspidocotylea. Interscience, New York, 699pp.

Zaghloul, K. H. (2001). Usage of zinc and calcium in inhibiting the toxic effect of copper on the Afriac catfish; Clarias gariepinus. J Basic Appl Zool, 35(C): 99-120.

Zaghloul, K. H.; Omar, W. A. and Abo-Hegab, S. (2005). Environmental hazard risk assessment on; Oreochromis niloticus and Tilapia zilli fish. J Basic Appl Zool, 46(A): 105-139. 